\title{
Therapeutic Effect of Milk Thistle (Silybum Marianum L) Seeds on Carbon Tetrachloride - Induced Hepatotoxicity in Rats
}

\author{
Dalia A. Zaki ${ }^{1}$, Azza S. Abdel-Ghany ${ }^{1}$ and Ayman Gomaa ${ }^{2}$
}

\begin{abstract}
The current research aimed to investigate the therapeutic effect of milk thistle (Silybum marianum L) seeds (MTS) powder compared with hepaticum drug on carbon- tetrachloride $\left(\mathrm{CCl}_{4}\right)$ caused hepatotoxicity in rats. Thirty six female albino rats weighting $140 \pm 20 \mathrm{~g}$ were divided into 6 groups. The $1^{\text {st }}$ group was fed on basal diet as the negative control group (G1), while the other five groups were injected by $\mathrm{CCl}_{4}$ (i.p). The $2^{\text {nd }}$ group was the positive control group (G2). Groups from $3^{\text {rd }}$ to $5^{\text {th }}$ were fed on basal diet contain different ratio of MTS powder 1, 2 and $3 \%$,respectively. While, the last group (G6) was fed on basal diet contain the hepaticum drug. Liver weight, relative liver weight to the body weight $(\mathrm{L} / \mathrm{B} \%)$, serum liver enzymes activity, total protein, albumin, bilirubin, kidney function, serum lipid profile and histopathological examination were determined. All data were statistically analyzed and the results showed that, milk thistle seeds are rich in protein, fat and fiber. Also, its oil rich in fatty acids as linoleic acid $(\mathbf{5 5 . 1 2} \%)$, oleic acid $(\mathbf{2 1 . 7 8 \%})$ and palmitic acid $(8.80 \%)$. Feeding hepatotoxic rats with $3 \%$ of MTS and drug caused a significant $(P \leq 0.05)$ increase in liver weight compared to the positive control group. While, there was no significant differences $(P>0.05)$ between the positive control group and therapeutic groups for $\mathrm{L} / \mathrm{B} \%$. On the other hand, adding 1, 2 and 3\% of MTS to standard diet caused a significant decrease $(P \leq 0.05)$ in ALT and AST enzymes activities level compared to the positive control group. Also, feeding hepatotoxic rats on 1, 2 and $3 \%$ of MTS and drug caused a significant $(P \leq \mathbf{0 . 0 5})$ decrease in serum urea and creatinine levels. So, by increasing the levels of adding MTS powder ( 2 and $3 \%$ ) to standard diet caused a significant improvement in liver function and histopathological examination.
\end{abstract}

Keywords: Milk thistle seeds, fatty acids, hepaticum drug, hepatotoxicity, $\mathrm{CCl}_{4}$, liver function.

\section{INTRODUCTION}

Milk thistle (Silybum marianum L) seeds (MTS) have been used for centuries as herbal medicine mainly for treatment of the liver disease. These seeds had a positive effect on liver because they contain about 26.2 $\mathrm{mg} / \mathrm{g}$ of silymarin which is a mixture of four isomeric flavonolignans including: silibinin, isosilibinin, silichristin, and silidianin (Post-White et al., 2007 and Dočkalová et al., 2018). Also, the seeds contain other bioactive compounds such as betaine, apigenin, silybonol, proteins, fixed oil and free fatty acids which play a good role in protection or treatment liver from inflammation (Evans, 2002 and Rainone, 2005). Silymarin has being currently used for treatment of chronic hepatitis, cirrhosis and liver diseases associated with alcohol consumption and environmental toxin exposure (Gazá et al., 2007 and Imamoto et al., 2014). In general, the content of milk thistle seeds from silymarin depends on the geographic, variety and climatic conditions in area which they grow (Ozturk et al., 2012).

Silymarin can exert beneficial effects on the balance of cell survival and apoptosis via anti-inflammatory and anti-oxidative effects to prevent or treat liver diseases (Diao et al., 2011). Also, it has an inhibitory effect on others types of cancer cell lines such as bladder, colon, prostate, lung and skin cancers (Feher and Lengyel, 2012). Silymarin is able to increase cellular vitality and reduce both lipid peroxidation and cellular necrosis because it have a high antioxidant activity power. Furthermore, it has an important biological effects on non-alcoholic fatty liver disease by intervening in various therapeutic targets, oxidative stress, insulin resistance, liver fat accumulation and mitochondrial dysfunction (Federico et al., 2017)

Liver is considered the most organ had sensitivity for carbon tetrachloride $\left(\mathrm{CCl}_{4}\right)$, it is one of the oldest and the most hepatotoxic chemical agents which used widely for biological experimental by induction liver injury or damage on animals (Lien et al.,2016). Carbon tetrachloride when metabolized in the body is changed into trichloromethyl which a very reactive free radicals that then induce liver damage. These free radicals caused cellular oxidative stress, necrosis and inflammation cell damage by two different mechanisms, the first mechanism including of covalent binding to the membrane proteins then cause lipid peroxidation, which leads to hepatic damages such as fibrosis, cirrhosis, and atrophy (Kanter et al., 2003 and Hsu et al., 2012).

DOI: 10.21608/ASEJAIQJSAE.2019.26436

${ }^{1}$ Food Science Department (Rural Home Economics), Faculty of Agriculture,

Zagazig University, Zagazig, Egypt.

2- Biochemistry Department, Faculty of Agriculture, Zagazig University, Zagazig, Egypt.

Corresponding authors: leen_swelam@yahoo.com

Received December 27, 2018, Accepted February 03, 2019 
Therefore, The present research aim to study the therapeutic effect of milk thistle (Silybum marianum L) seeds at different ratio and compared with hepaticum drug on carbon tetrachloride $\left(\mathrm{CCl}_{4}\right)$ - induced hepatotoxicity in rats.

\section{MATERIALS AND METHODS}

\section{Materials :}

Milk thistle seeds was obtained from Horticulture Department, Faculty of Agriculture, Zagazige

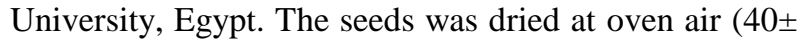
$2^{\circ} \mathrm{C}$ ) for $6 \mathrm{~h}$. The dried seeds were powdered using hammer mill and stored in a tightly sealed plastic container in the freezer (Toshiba company) at $-5^{\circ} \mathrm{C}$ for further uses and analysis. Hepaticum syrup drug was obtained from local pharmacy.

Carbon tetrachloride $\left(\mathrm{CCl}_{4}\right)$, paraffin oil, casein, cellulose, vitamins mixture and minerals mixture were obtained from El-Gomhoria Company for Chemicals and Medical Instruments, Cairo, Egypt. Corn oil and starch were obtained from the local market. Kits for analysis were purchased from Sigma -Aldrich (MO,IL, USA). A 36 adult female albino rats (Sprague Dawley strain) weighting average $140 \pm 20 \mathrm{~g}$ were obtained from the Helwan breeding Farm, Cairo, Egypt.

The basal diet were prepared according to N.R.C. (1995). This diet consisted of $12.5 \%$ casein, $10 \%$ corn oil, $4 \%$ salt mixture, $1 \%$ vitamin mixture, $5 \%$ cellulose, $0.3 \%$ DL- methionine, $0.2 \%$ Choline chloride and completed to $100 \%$ by corn starch.

\section{Methods:}

\section{Proximate chemical composition:}

Moisture, protein, ash, fat and crude fiber were estimated for milk thistle seeds powder according to AOAC (2005). Total carbohydrate content was calculated by difference.

\section{Gas Chromatographic determination of fatty acids:}

The oil was extracted in a soxhlet apparatus according to AOAC (2005) by using approximately $10 \mathrm{~g}$ of the ground seeds. Saponification and esterification of the oil was performed according to Hartman and Lago (1973). The fatty acid methyel esters were analyzed using a gas chromatography (type HP 6890, UK) equipped with flam ionization detector. Column was DB-23, 30m, $0.32 \mathrm{~mm}$ ID and $0.25 \mu \mathrm{m}$ film thickness. The column oven temperature was held for $5 \mathrm{~min}$ at $140^{\circ} \mathrm{C}$, then programmed at rate of $4^{\circ} \mathrm{C} / \mathrm{min}$ to a final temperature of $210^{\circ} \mathrm{C}$ and held for $0 \mathrm{~min}$. Injector temperature was $240^{\circ} \mathrm{C}$, and the injector port was $3 \mu \mathrm{l}$ with a 50:1 split ratio. The flow rate of nitrogen as carrier gas was adjusted to $1 \mathrm{ml} / \mathrm{min}$. Identification of the peaks was carried out by their retention time (AOAC, 2005).

\section{Animals experimental design:}

Albino female rats were housed in well aerated cages under hygienic laboratory conditions, in the animal house of Faculty of Agriculture, Zagazig University. All animals were given water ad libitum and the basal diet that meets the nutrient requirements for growing rats. After 7 days of acclimation, the rats were randomly classified into 6 groups ( 6 rats each) as follow:

- The first group (G1): negative control group injected with corn oil intraperitoneal (i.p) and fed on basal diet.

- The second group (G2): positive control group injected with corn oil dissolved in $\mathrm{CCl}_{4}$ at ratio 1:1 (i.p) according to Lee et al. (2005), then fed on basal diet.

- The third group (G3) after being injected with $\mathrm{CCl}_{4}$, they were fed on basal diet $+1 \%$ milk thistle seeds powder.

- The fourth group (G4) after being injected with $\mathrm{CCl}_{4}$, they were fed on basal diet $+2 \%$ milk thistle seeds powder.

- The fifth group (G5) after being injected with $\mathrm{CCl}_{4}$, they were fed on basal diet $+3 \%$ milk thistle seeds powder.

- The sixth group (G6) after being injected with $\mathrm{CCl}_{4}$, it were fed on basal diet + hepaticum syrup drug at dose $10 \mathrm{mg}$ silymarin/Kg of body weight.

During the experimental period 30 days, the quantities of food intake and waste were recorded every day and body weight was recorded every week.

\section{Biochemical analysis of blood samples:}

After 30 days rats were fasted overnight then they were ether-anesthetized, and sacrificed. Blood samples were collected from the aorta by using Wassermann and EDTA tubes were used to collect serum and plasma samples. Then they were centrifuged for 20 minutes at $3000 \mathrm{rpm}(800 \mathrm{xg})$ to separate serum and plasma. The serum and plasma were carefully separated into dry clean ebendorf tubes by using a Pasteur pipette and kept frozen at $-20^{\circ} \mathrm{C}$ till analysis. Liver was removed from each rat carefully then cleaned from the adhesive matter by saline solution, dried between a filter paper and weighted.

\section{Liver function:}

Total protein was determined according to Sonnenwirth and Jaret (1980). Aspartate aminotransferase (AST) and alanine aminotransferase (ALT) were determined according to Retiman and Frankel (1957), total bilirubin was estimated according to Jendrassik (1938) and albumin was determined according to Drupt (1974) 


\section{Kidney function:}

Urea was estimated according to Fawcett and Soctt (1960). Creatinine was estimated according to the methods described by Larsen (1972).

\section{Lipide profile:}

Total cholesterol (TC), triglycerides (TG) and high density lipoprotein (HDL) were determined according to the methods of Young (2001), Stein (1987) and Lopes et al. (1977), respectively. Low density lipoprotein (LDL) and very low density lipoprotein (VLDL) were calculated by using the method of Friedewald et al. (1972) .

\section{Histopathological examination of liver:}

The formalin preserved liver tissue samples of tested rats and controls were processed in an automated tissue processor. The processing consisted of an initial 2 step fixation and dehydration. Fixation comprising tissue immersion in $10 \%$ buffered formalin for $48 \mathrm{~h}$, followed by removal of fixative in distilled water for $30 \mathrm{~min}$. Dehydration was carried out by running the tissues through a graded series of alcohol $(70 \%, 90 \%$ and $100 \%$ ). The tissue was initially exposed to $70 \%$ alcohol for 120 min followed by $90 \%$ alcohol for $90 \mathrm{~min}$ and then two cycles of absolute alcohol, each for hour. The samples were cleaned in several changes of xylene. It consisted of tissue immersion for hour in a mixture comprising 50\% alcohol and 50\% xylene followed by pure xylene for $90 \mathrm{~min}$. Samples were impregnated with molten paraffin wax, then embedded and blocked out. Paraffin sections (4-5 um) were stained with hematoxylin and eosin, the conventional staining technic (Suvarna et al., 2013). Stained sections from different experimental rats were evaluated for any alterations in the architecture, histomorphological changes, circulatory disturbances, inflammation granulomas, fibrosis, degeneration, necrosis and any other abnormalities.

\section{Statistical analysis:}

All statistical analyses were done by statistical analysis for social science package "SPSS" version 20 for Microsoft windows, SPSS Inc. (Dominick and Derrick, 2001). Numerical data were expressed as mean $\pm \mathrm{SD}$. The levels of markers were analyzed by least significant difference (LSD).

\section{RESULTS AND DISCUSSION}

\section{Proximate chemical composition of milk thistle seeds} powder:

The data in Table (1) show that the moisture, crude protein, crude fat, crude fiber, ash and carbohydrate of milk thistle seeds powder were 8.53, 22.43, 30.52, $20.51,4.65$, and $13.36 \%$, respectively. It is observed from the data that milk thistle seeds are rich in its content of nutrients as protein, fat, fiber and ash which can use it as functional ingredient for supplementation foods and medical purposes.

Table 1. Proximate chemical composition of milk thistle seeds powder

\begin{tabular}{lc}
\hline \multicolumn{1}{c}{ Proximate composition } & $\begin{array}{c}\text { Value (\%) } \\
\text { Mean } \pm \text { S.D. }\end{array}$ \\
\hline Moisture & $8.53 \pm 0.20$ \\
Crude protein & $22.43 \pm 0.86$ \\
Crude fat & $30.52 \pm 1.42$ \\
Ash & $4.65 \pm 0.03$ \\
Crude fiber & $20.51 \pm 1.53$ \\
Carbohydrate & $13.36 \pm 2.46$ \\
\hline
\end{tabular}

Fatty acids composition of milk thistle seed oil:

Fatty acids composition of milk thistle seed oil are shown in Table (2). Linoleic acid (55.12\%) was the major fatty acid followed by oleic acid (21.78\%), palmitic acid $(8.80 \%)$, stearic acid $(6.78 \%)$, arachidic acid $(3.45 \%)$ and behenic acid (2.04\%). Meanwhile, gadolic acid, vaccenic acid, linolenic acid, eicosapentaenoic acid and arachidonic acid were found in small amounts. It is noted from the data that milk thistle seed oil had high content of fatty acids which may be had a good role on therapeutic hepatotoxicity or protection liver from inflammation. The obtained results are in line with (Rainone, 2005).

Table 2. Fatty acids composition of milk thistle seeds

\begin{tabular}{lcc}
\hline \multicolumn{2}{c}{ Fatty acids } & \multirow{2}{*}{ \% Fatty acid } \\
\hline Common name & Symbol & \\
\cline { 1 - 2 } Palmitic acid & $\mathrm{C} 16: 0$ & 8.80 \\
Stearic acid & $\mathrm{C} 18: 0$ & 6.78 \\
Oleic acid & $\mathrm{C} 18: 1 \omega 9$ & 21.78 \\
Vaccenic acid & $\mathrm{C} 18: 1 \omega 7$ & 0.49 \\
Linoleic acid & $\mathrm{C} 18: 2 \omega 6$ & 55.12 \\
Linolenic acid & $\mathrm{C} 18: 3 \omega 3$ & 0.21 \\
Arachidic acid & $\mathrm{C} 20: 0$ & 3.45 \\
Gadolic acid & $\mathrm{C} 20: 1 \omega 11$ & 0.83 \\
Arachidonic acid & $\mathrm{C} 20: 4 \omega 6$ & 0.16 \\
Eicosapentaenoic & $\mathrm{C} 20: 5 \omega 3$ & 0.20 \\
acid & $\mathrm{C} 22: 0$ & 2.04 \\
Behenic acid & & 21.07 \\
Total saturated \% & & 78.79 \\
Total unsaturated \% & & 0.14 \\
Non identified fatty acids \% & \\
\hline
\end{tabular}

\section{Effect of milk thistle seeds on liver weight:}

The results in Table (3) show the effect of milk thistle seeds powder (1,2 and 3\%) and drug on liver weight and relative liver weight to the body weight (L/B). Administration rats by $\mathrm{CCl}_{4}(\mathrm{G} 2)$ caused a significant decrease $(P \leq 0.05)$ in liver weight $(6.13 \mathrm{~g})$ 
compared to the negative control group (G1) (7.25g). On the other hand, feeding hepatotoxic rats with $3 \%$ of milk thistle seed powder (MTS) (G5) and drug (G6) caused a significant $(P \leq 0.05)$ increase in liver weight compared to positive control group (G2). Moreover, results for $\mathrm{L} / \mathrm{B}$ ratio showed that there were no significant differences $(P>0.05)$ between the positive control group $(2.92 \%)$ and therapeutic groups (2.87, $2.78,2.73$ and $2.82 \%$ for G3, G4, G5 and G6, respectively). The obtained results are agree with Hussein and Salah (2016) found that there were no significant differences between hepatotoxic rats (+ve) group and treated groups on different ratio of fresh parsley at 5, 10 and 20\% for L/B ratio. Also, Lien et al., (2016) revealed that treatment hepatotoxicity rats with silymarin $18 \mathrm{mg} / \mathrm{kg}$ b.w. reduced $\mathrm{L} / \mathrm{B}$ to $82.7 \%$, this result may be refer to the protective effects of silymarin on liver damage with administration by $\mathrm{CCl}_{4}$. Dočkalová et al. ( 2018) stated that feeding rats on basal diet containing 10 and $20 \%$ MTS caused a significant increases in weight gain compared to the control group.

Table 3. Effect of milk thistle seeds powder and drug on liver weight and relative for body weight $(\mathrm{L} / \mathrm{B})$ of hepatotoxic rats

\begin{tabular}{lcc}
\hline \multicolumn{1}{c}{ Groups } & Liver weight $(\mathrm{g})$ & $\mathrm{L} / \mathrm{B}(\%)$ \\
\hline G1(-ve) & $7.25 \pm 0.53^{\mathrm{a}}$ & $3.13 \pm 0.22^{\mathrm{a}}$ \\
G2(+ve) & $6.13 \pm 0.21^{\mathrm{c}}$ & $2.92 \pm 0.07^{\mathrm{b}}$ \\
G3(1\% MTP) & $6.37 \pm 0.03^{\mathrm{bc}}$ & $2.87 \pm 0.05^{\mathrm{b}}$ \\
G4(2\% MTP) & $6.44 \pm 0.04^{\mathrm{bc}}$ & $2.78 \pm 0.08^{\mathrm{b}}$ \\
G5(3\% MTP) & $6.79 \pm 0.28^{\mathrm{ab}}$ & $2.73 \pm 0.15^{\mathrm{b}}$ \\
G6(syrup & $7.13 \pm 0.14^{\mathrm{a}}$ & $2.82 \pm 0.03^{\mathrm{b}}$ \\
drug) & & 0.21 \\
LSD & 0.47 & \\
\hline
\end{tabular}

Means with the different small letters in each column are significantly at $P \leq 0.05$.

\section{Effect of milk thistle seeds powder on liver function:}

In this study, many parameters were used to evaluate the effect of feeding hepatotoxic rats with different ratio of MTS powder and hepaticum drug on liver function.
Results in Table (4) showed that the positive control group $(\mathrm{G} 2)$ had significantly $(P \leq 0.05)$ the highest value of total protein $(7.70 \mathrm{mg} / \mathrm{dl})$ compared to the negative control group (G1) and G5 which fed on 3\% MTS powder $(7.23 \mathrm{mg} / \mathrm{dl}$ and $7.33 \mathrm{mg} / \mathrm{dl}$, respectively). On the other hand, there was no significant $(P>0.05)$ different between drug group (G6) and the negative control group (G1) in serum total protein. Concerning serum ALT enzyme levels result showed that there were a significant $(P \leq 0.05)$ decrease in ALT values for the treatment groups (G3, G4, G5, G6) and the negative control group (G1) compared to the positive control group (G2). Moreover, it could be observed that the positive control group $(\mathrm{G} 2)$ had a significant $(P \leq 0.05)$ increase in the mean value of AST $(33.00 \mathrm{mg} / \mathrm{dl})$ compared to the negative control (G1) $(25.27 \mathrm{mg} / \mathrm{dl})$ and there was no significant $(P>0.05)$ differences between hepatotoxic rats fed on 2 and 3\% MTS (G4 and G5) and drug group (G6) compared to the negative control (G1).

Also from the results in Table (4), it is evident that there were a significant $(P \leq 0.05)$ differences in serum total bilirubin and albumin levels between the negative control group (G1) and the positive control group (G2). While, feeding hepatotoxic rats on MTS (1,2 and 3\%) and drug resulted in a significant $(P \leq 0.05)$ decrease for total bilirubin and albumin levels compared to the positive control group (G2). It is cleared from the data that fed hepatotoxic rats on MTS attenuated these adverse effects. These results are in line with Suja et al. (2004) and Ozturk et al. ( 2012) found that liver enzymes and bilirubin levels were increased by $\mathrm{CCl}_{4}$ administration and decreased by Silybum marianum treatment. Ismael et al.,(2014) cleared that feeding rats on stirred yoghurt with silymarin at different ratio 0.4, 0.6 and $0.8 \%$ caused significant lower in ALT and AST enzymes compared with group treated with $\mathrm{CCl}_{4}$. Also, these results are matched with Lien et al. (2016). Moreover, Wahid et al. (2016) demonstrated the effect of ethanolic extract of Salix subserrata flower against carbon tetrachloride -induced liver damage.

Table 4. Effect of milk thistle seeds powder and drug on liver function of hepatotoxic rats

\begin{tabular}{lccccc}
\hline \multicolumn{1}{c}{ Groups } & $\begin{array}{c}\text { Total protein } \\
(\mathbf{m g} / \mathbf{d l})\end{array}$ & $\begin{array}{c}\text { ALT } \\
(\mathbf{u} / \mathbf{l})\end{array}$ & $\begin{array}{c}\text { AST } \\
(\mathbf{u} / \mathbf{l})\end{array}$ & $\begin{array}{c}\text { Total bilirubin } \\
(\mathbf{m g} / \mathbf{d l})\end{array}$ & $\begin{array}{c}\text { Albumin } \\
(\mathbf{m g} / \mathbf{d l})\end{array}$ \\
\hline G1(-ve) & $7.23 \pm 0.31^{\mathrm{b}}$ & $65.37 \pm 5.20^{\mathrm{b}}$ & $25.27 \pm 1.89^{\mathrm{c}}$ & $0.67 \pm 0.06^{\mathrm{c}}$ & $3.27 \pm 0.15^{\mathrm{d}}$ \\
G2(+ve) & $7.70 \pm 0.20^{\mathrm{a}}$ & $99.43 \pm 0.75^{\mathrm{a}}$ & $33.00 \pm 2.19^{\mathrm{a}}$ & $0.99 \pm 0.11^{\mathrm{a}}$ & $4.13 \pm 0.06^{\mathrm{a}}$ \\
G3(1\% MTP) & $7.50 \pm 0.10^{\mathrm{ab}}$ & $67.77 \pm 2.70^{\mathrm{b}}$ & $29.60 \pm 0.78^{\mathrm{b}}$ & $0.82 \pm 0.03^{\mathrm{b}}$ & $3.87 \pm 0.13^{\mathrm{b}}$ \\
G4(2\% MTP) & $7.43 \pm 0.06^{\mathrm{ab}}$ & $59.23 \pm 1.33^{\mathrm{c}}$ & $27.50 \pm 0.78^{\mathrm{bc}}$ & $0.79 \pm 0.01^{\mathrm{b}}$ & $3.73 \pm 0.12^{\mathrm{bc}}$ \\
G5(3\% MTP) & $7.33 \pm 0.12^{\mathrm{b}}$ & $51.93 \pm 3.46^{\mathrm{d}}$ & $26.47 \pm 0.60^{\mathrm{c}}$ & $0.76 \pm 0.01^{\mathrm{bc}}$ & $3.83 \pm 0.16^{\mathrm{b}}$ \\
G6(syrup drug) & $7.43 \pm 0.06^{\mathrm{ab}}$ & $65.93 \pm 1.89^{\mathrm{b}}$ & $25.90 \pm 0.70^{\mathrm{c}}$ & $0.75 \pm 0.02^{\mathrm{bc}}$ & $3.57 \pm 0.15^{\mathrm{c}}$ \\
LSD & 0.29 & 5.25 & 2.35 & 0.09 & 0.23 \\
\hline
\end{tabular}

Means with the different small letters in each column are significantly at $P \leq 0.05$. 
This treatment was significantly $(P<0.001)$ capable of preventing the elevation in serum levels of liver enzymes and bilirubin.

\section{Effect of milk thistle seeds powder on kidney function :}

The data in Table (5) show the effect of feeding hepatotoxic rats on basal diet containing different ratio of MTS and drug on kidney function. There were a significant $(P \leq 0.05)$ differences in serum urea and creatinine levels between the negative control group (G1) and the positive control group (G2). Feeding hepatotoxic rats on 1,2 and $3 \%$ of MTS and drug caused a significant $(P \leq 0.05)$ decrease in serum urea and creatinine levels compared to the positive control group (G2). So, it is observed from the data that milk thistle seeds caused a significant $(P \leq 0.05)$ improvement in kidney function for hepatotoxic rats. The obtained results are matched with Ismael et al. (2014) and Wahid et al. (2016). Also, Ozturk et al. ( 2012) stated that treatment hepatotoxic rats with Silybum marianum caused slightly insignificant decrease in urea and creatinine levels compared to group injected by $\mathrm{CCl}_{4}$.

Table 5. Effect of milk thistle seeds powder and drug on kidney function of hepatotoxic rats

\begin{tabular}{lcc}
\hline \multirow{2}{*}{ Groups } & \multicolumn{2}{c}{ Kidney function } \\
\cline { 2 - 3 } & $\begin{array}{c}\text { Urea } \\
(\mathrm{mg} / \mathrm{dl})\end{array}$ & $\begin{array}{c}\text { Creatinine } \\
(\mathrm{mg} / \mathrm{dl})\end{array}$ \\
\hline G1(-ve $)$ & $42.70 \pm 2.09^{\mathrm{c}}$ & $0.63 \pm 0.03^{\mathrm{e}}$ \\
G2(+ve) & $54.47 \pm 3.07^{\mathrm{a}}$ & $0.89 \pm 0.04^{\mathrm{a}}$ \\
G3(1\% MTP) & $48.00 \pm 0.96^{\mathrm{b}}$ & $0.80 \pm 0.05^{\mathrm{b}}$ \\
G4(2\% MTP) & $45.13 \pm 1.05^{\mathrm{bc}}$ & $0.76 \pm 0.04^{\mathrm{bc}}$ \\
G5(3\% MTP) & $47.63 \pm 2.14^{\mathrm{b}}$ & $0.73 \pm 0.02^{\mathrm{cd}}$ \\
G6(syrup drug) & $45.47 \pm 0.57^{\mathrm{bc}}$ & $0.69 \pm 0.02^{\mathrm{de}}$ \\
LSD & 3.30 & 0.06 \\
\hline
\end{tabular}

Means with the different small letters in each column are significantly at $P \leq 0.05$.

Table 6.Effect of milk thistle seeds powder and drug on lipid profile of hepatotoxic rats

\begin{tabular}{lccccc}
\hline \multirow{2}{*}{ Groups } & \multicolumn{5}{c}{ Lipid profile } \\
\cline { 2 - 6 } & $\begin{array}{c}\text { TG } \\
(\mathbf{m g} / \mathbf{d l})\end{array}$ & $\begin{array}{c}\text { TC } \\
(\mathbf{m g} / \mathbf{d l})\end{array}$ & $\begin{array}{c}\text { HDL } \\
(\mathbf{m g} / \mathbf{d l})\end{array}$ & $\begin{array}{c}\text { LDL } \\
(\mathbf{m g} / \mathbf{d l})\end{array}$ & $\begin{array}{c}\text { VLDL } \\
(\mathbf{m g} / \mathbf{d l})\end{array}$ \\
\hline G1(-ve) & $77.67 \pm 2.45^{\mathrm{d}}$ & $117.43 \pm 2.56^{\mathrm{d}}$ & $61.60 \pm 3.87^{\mathrm{ab}}$ & $40.30 \pm 3.94^{\mathrm{d}}$ & $15.53 \pm 0.49^{\mathrm{d}}$ \\
G2(+ve) & $113.30 \pm 6.90^{\mathrm{a}}$ & $153.87 \pm 6.12^{\mathrm{a}}$ & $52.03 \pm 2.77^{\mathrm{d}}$ & $79.17 \pm 5.47^{\mathrm{a}}$ & $22.66 \pm 1.38^{\mathrm{a}}$ \\
G3(1\% MTP) & $101.27 \pm 4.94^{\mathrm{b}}$ & $138.50 \pm 4.49^{\mathrm{b}}$ & $55.53 \pm 1.60^{\mathrm{cd}}$ & $62.71 \pm 3.58^{\mathrm{b}}$ & $20.25 \pm 0.99^{\mathrm{b}}$ \\
G4(2\% MTP) & $86.90 \pm 1.20^{\mathrm{c}}$ & $128.13 \pm 1.86^{\mathrm{c}}$ & $57.57 \pm 2.15^{\mathrm{bc}}$ & $53.19 \pm 3.86^{\mathrm{c}}$ & $17.38 \pm 0.24^{\mathrm{c}}$ \\
G5(3\% MTP) & $79.87 \pm 2.15^{\mathrm{d}}$ & $119.53 \pm 2.72^{\mathrm{d}}$ & $63.77 \pm 1.96^{\mathrm{a}}$ & $39.79 \pm 3.38^{\mathrm{d}}$ & $15.97 \pm 0.43^{\mathrm{d}}$ \\
G6(syrup drug) & $84.40 \pm 2.57^{\mathrm{cd}}$ & $123.50 \pm 1.42^{\mathrm{cd}}$ & $58.73 \pm 1.84^{\mathrm{bc}}$ & $47.89 \pm 3.32^{\mathrm{c}}$ & $16.88 \pm 0.51^{\mathrm{cd}}$ \\
LSD & 6.92 & 6.37 & 4.42 & 7.10 & 1.38 \\
\hline
\end{tabular}

Means with the different small letters in each column are significantly at $P \leq 0.05$.
Effect of milk thistle seeds powder on lipid profile:

It was observed from Table (6) that the mean values of TG, TC, LDL and VLDL for positive group (G2) were significantly $(P \leq 0.05)$ higher compared to the negative control group (G1). The TG, TC, LDL and VLDL values of rat groups fed on MTP and syrup drug (G3, G4, G5 and G6) were significantly $(P \leq 0.05)$ lower as compared with the positive group (G2). Also, it could be noticed that the positive control group (G2) appeared significant $(P \leq 0.05)$ decrease in HDL values compared to G1. However, there was no significant difference between rat groups fed on syrup drug and rats fed on 2 and 3\% MTP for TG, TC and VLDL. The rat groups fed on $3 \%$ MTP had significantly $(P \leq 0.05)$ a high levels of HDL and low levels of LDL compared to G2, G3, G4 and G6. Some previous studies have stated that polyphenolics of plants increase the liver secretion of apoA-I and positively modifies lipoprotein profile in plasma (Theriault et al., 2000 and Škottová et al., 2003). So, in this study, the increase of HDL in rats fed on MTP may be due to MTS polyphenolic property on apoA-I metabolism.

Therefore, feeding rats on diets containing MTS powder led to significant improvement on lipid profile which the rate of effective was increased by increasing the ratio of MTP. Moreover, Dabbour et al. (2014) reported that the ratio of MTS oil was the main factors affecting the lipid profile. Heidarian and RafieianKopaei (2012) found that the plasma levels of TC, LDL, VLDL, liver cholesterol and liver TG in rats treated with silymarin decreased compared to hyperlipidemic rats and negative control. Thus, silymarin is introduced as lipid-lowering therapeutic agent and counteracts the development of fatty liver. 


\section{Histopathological examination of liver:}

Histopathological examination of the liver sections for the negative control group (G1) fed only on basal diet showed normal histomorphological structures included central vein, hepatic sinusoids, cords and portal triads as shown in Fig. (1). While, the positive control group (G2) injected by $\mathrm{CCl}_{4}$ showing many severe toxicity lesions manifested by widening and severe congested of hepatic blood vessels. Moreover, congested portal blood vessels, focal periportal inflammatory aggregates were also seen. In addition to severe periportal fibrosis infiltrated by macrophages with newly bile ductules formation followed by some apoptotic hepatocytes could be observed. The hepatic cords showed individual apoptosis of hepatocytes with mild widening and congestions of sinusoids. A few hepatic sections revealed portal collagen fiber deposits followed by massive degenerations of hepatocytes as seen in Figs. ( 2 a \& b).

Moreover, as shown in Figs. ( 3 a \& b) the majority lesions in this group (G3, rats injected with $\mathrm{CCl}_{4}+\mathrm{fed}$ on standard diet contain 1\% MTS) represented by moderate congested blood vessels some of the surrounded by mild periportal inflammatory cells aggregations. On the other hand, focal lymphocytic aggregation beside a few apoptotic hepatocytes were noted. Other examined sections revealed severe degeneration of hepatocytes with very widening of sinusoids .

The hepatotoxic rats fed on basal diet contain $2 \%$ MTS (G4) characterized mild to moderate portal fibrosis infiltrated by many lymphocytes and macrophages.
Other sections exhibited by small bridges fibrosis between portal areas with minute inflammatory cells. The remaining sections showed within the normal hepatic architectures except one portal area with minute fibrosis. Meanwhile, normal portal areas with very congested sinusoids were seen and majority of sections showed normal hepatic portal area (Figs. 4 a \& b). Fed hepatotoxic rats on 3\% MTS (G5) showed the majority of portal areas are normal histomorphological structures with mild congested blood vessel. Moreover, normal portal areas with a few lymphocytic aggregations were noted as shown in Figs $(5 \mathrm{a} \& \mathrm{~b})$. The histological examination of hepatotoxic rats treated with drug syrup (G6) appeared normal portal areas with mild congested blood vessels as shown in Figs. ( 6 a \& b).

The obtained results are in line with Ozturk et al. (2012) found that treatment hepatotoxic rats with Silybum marianum caused slightly preventive effect on $\mathrm{CCl}_{4}$ induced liver damage by histologically. Alkaladi and Abdelazim (2013) noted the protective role of silymarin in rats- liver tissues damage induced by chemical carcinogenesis. Also, Ismael et al. (2014) studied the histopathological changes in liver tissues of hepatotoxic rats groups fed on stirred yoghurt contained $0.4,0.6$ and $0.8 \%$ silymarin. The results showed improvement in liver tissues compared to positive group. The obtained results are matched with Malhi et al. (2015) and Wahid et al. (2016). Also, with Dočkalová et al. (2018) who found that rats fed on basal diet contain 10 and $20 \%$ of milk thistle pressed parts caused a lower in liver steatosis which may refer to the hepatoprotective effects of silymarin

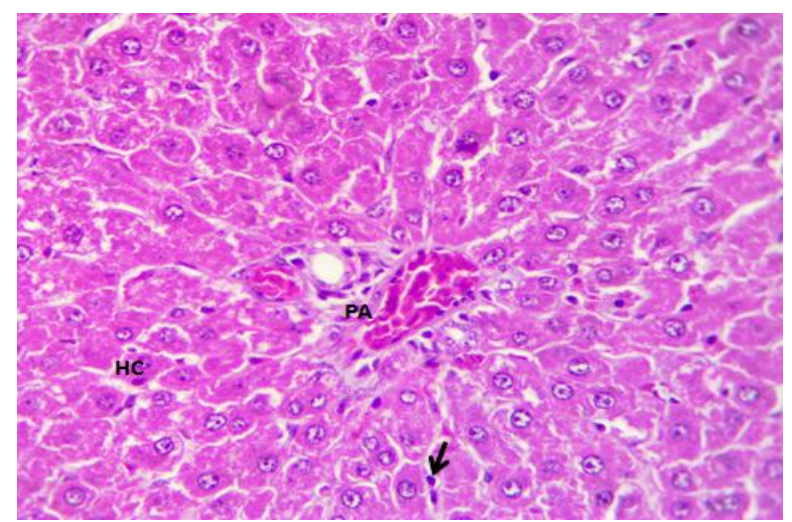

Fig. 1. Photomicrograph of liver section of negative control group (G1) showing normal portal triads (PA) including hepatic artery, vein and bile ductules followed by normal hepatocytes arranged as hepatic cords (HC) and normal kupffer cells among limit widening of sinusoids (arrow) H\&E stain X400 


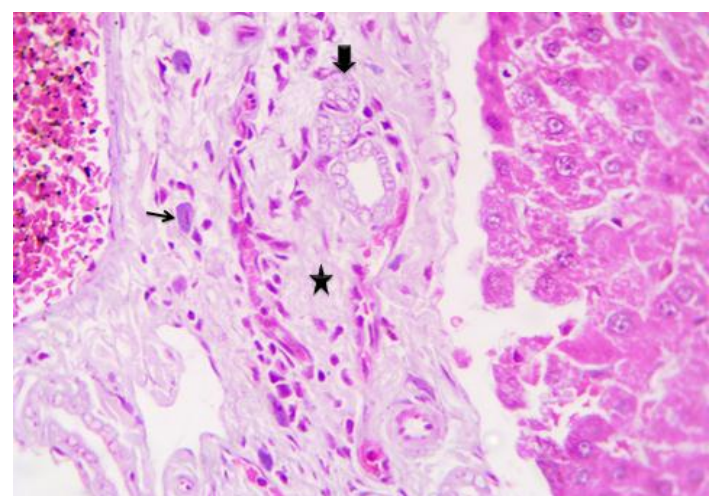

Fig. 2a.Photomicrograph of liver section of positive control group (G2) showing severe periportal fibrosis infiltrated by macrophages (thin arrow), with newly bile ductules formation (thick arrow) followed by some apoptotic hepatocytes. H\&E stain X400

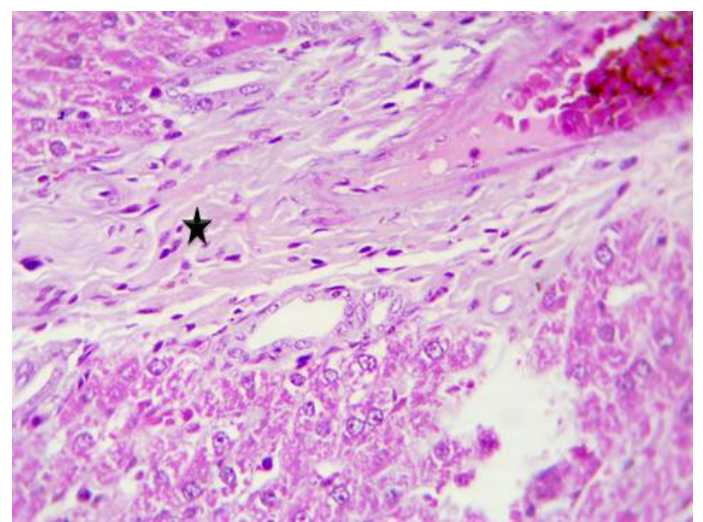

Fig. 2b.Photomicrograph of liver section of positive control group (G2) showing portal collagen fiber deposits (star) followed by massive degenerations of hepatocytes. H\&E stain X400

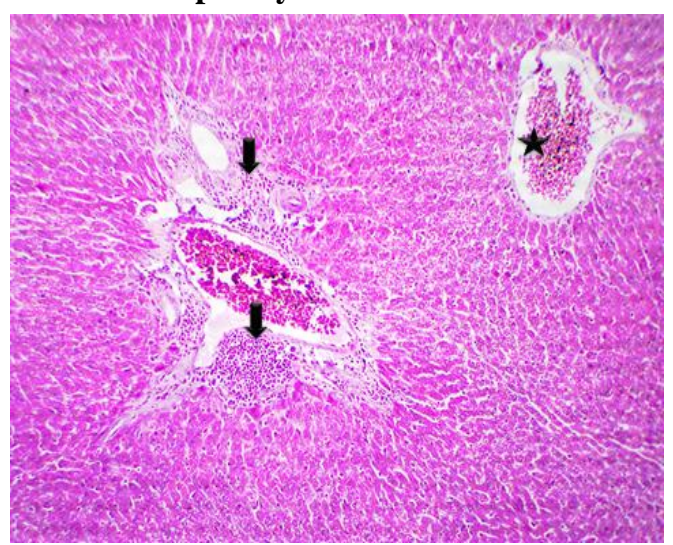

Fig. 3a. Photomicrograph of liver section of the hepatotoxic rats treated with 1\% MTS (G3) showing mild congested blood vessels (star) beside mild periportal inflammatory cells aggregations (arrows). H\&E stain X100 


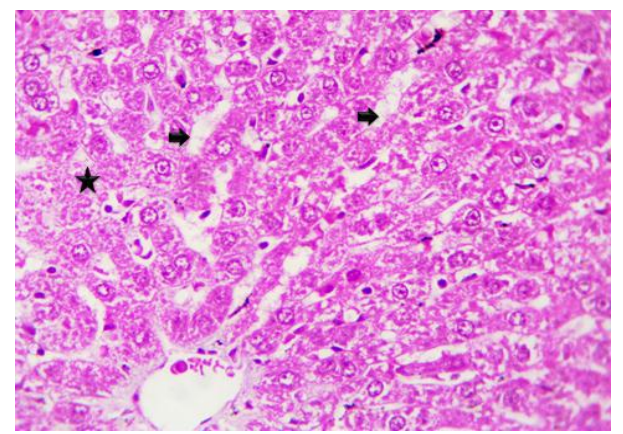

Fig. 3b.Photomicrograph of liver section of rats of the hepatotoxic rats treated with $1 \%$ MTS (G3) $1 \%$ MTS (G3) showing severe degeneration of hepatocytes (star) with very widening of sinusoids (arrows). H\&E stain X400

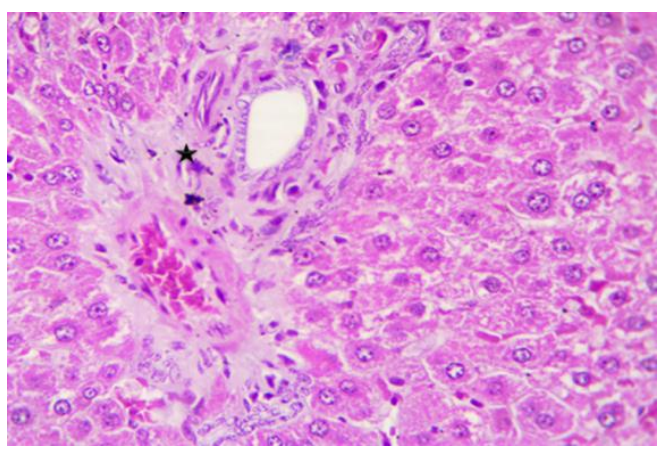

Fig. 4a. Photomicrograph of liver section of the hepatotoxic rats treated with $2 \%$ MTS (G4) showing normal portal areas with minute fibrosis (star). H\&E stain X400

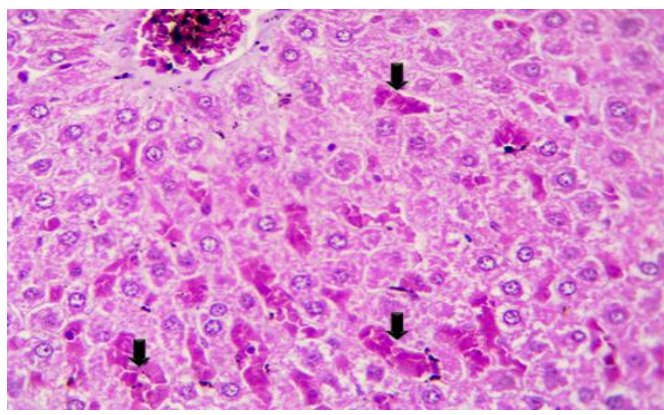

Fig. 4b. Photomicrograph of liver section of the hepatotoxic rats treated with 2\% MTS (G4) showing normal portal areas with very congested sinusoids (arrows). H\&E stain X400

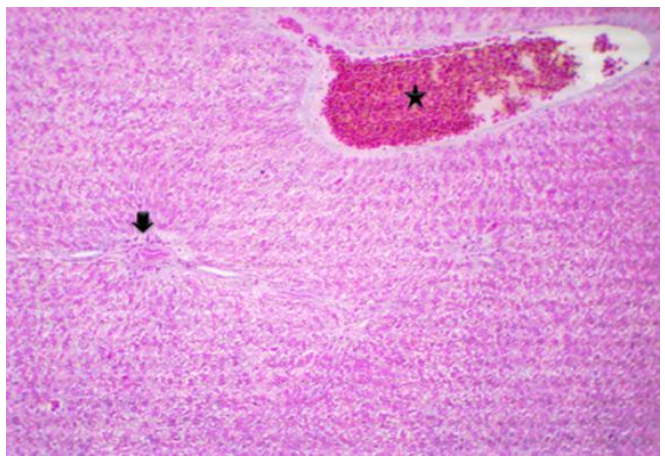

Fig. 5a. Photomicrograph of liver section of the hepatotoxic rats treated with 3\% MTS (G5) showing normal portal area with moderate congested blood vessel (star). H\&E stain X100 


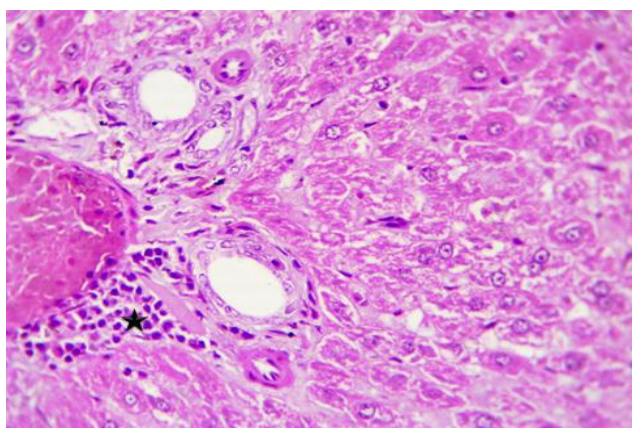

Fig. 5b.Photomicrograph of liver section of the hepatotoxic rats treated with 3\% MTS (G5) showing normal portal areas with a few lymphocytic aggregations (star). H\&E stain X400

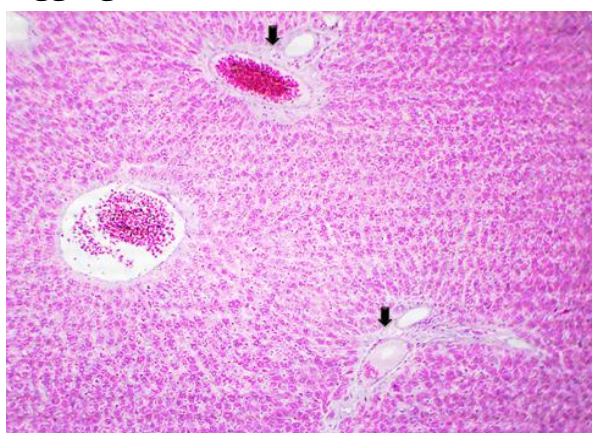

Fig. 6a. Photomicrograph of liver section of the hepatotoxic rats treated with drug syrup (G6) showing nearly normal portal areas (arrows) with mild congested blood vessels. H\&E stain X100

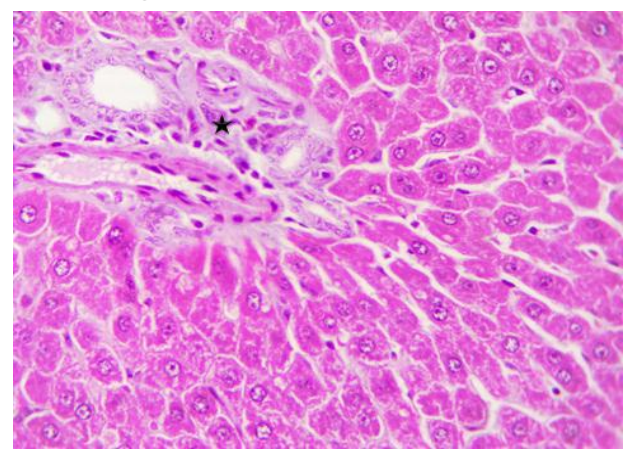

Fig. 6b. Photomicrograph of liver section of hepatotoxic rats treated with drug syrup (G6) showing nearly normal portal area. H\&E stain X400

\section{CONCLUSIONS}

It could be concluded from the current research that, milk thistle seeds are rich in protein, fat, fiber, ash and fatty acids. In addition, feeding hepatotoxic rats on standard diet supplemented with high ratio of MTS showed a significant improvement in liver function, lipid profile and kidney function parameters similar to hepaticum drug. So, this study recommends the ability of using milk thistle seeds as functional ingredients in processing functional food products which can play good role in protecting liver and helping liver patients during therapeutic period.

\section{REFERENCES}

AOAC.2005. Official Methods of Analysis. $18^{\text {th }}$ ed. Association of Official Analytical Chemists, Washington, D.C, USA.

Alkaladi, A. and A. M. Abdelazim. 2013. Improved antiInflammatory effect of silymarin in rats induced liver carcinogenesis. World applied Sci. J. 21(2): 176-180.

Dabbour, I. R., M. N. Ahmad, H. R. Takruri, and K. M. AlIsmail.2014. Effect of chemical properties of milk thistle seed oil on serum lipid profile and antioxidants capacity in rats fed high cholesterol and cholesterol free diets. Pakistan J. Nutr. 13(10): 600-609. 
Diao, Y., X. F. Zhao, J. S. Lin, Q. Z. Wang and R. A. $\mathrm{Xu} .2011$. Protection of the liver against $\mathrm{CCl}_{4}$-induced injury by intramuscular electro-transfer of a kallistatinencoding plasmid. World J. Gastroentero.,17: 111-117.

Dočkalová, H., P. Horký, L. Zeman and J. Skládanka. 2018. Influence of milk thistle pressed parts on rats liver histology. Potravinarstvo Slovak J. Food Sci.,12(1): 3339.

Dominick, S. and R. Derrick. 2001. Theory and Problems of Statistics and Econometrics. Second Edition. New York. p. 202.

Drupt, F. 1974. Colorimetric method for determination of albumin. Pharm.Biol., 9: 777-779.

Evans, W. C. 2002. Trease and evans pharmacognosy. $15^{\text {th }} \mathrm{ed}$. Reed Elsevier India Pvt. Ltd, New Delhi.

Fawcett, J. K. and J. E. Soctt. 1960. A rapid and precise method for the determination of urea. J. Clinc. Path., 13: 156-159.

Federico, A., M. Dallio and C. Loguercio. 2017. Silymarin/silybin and chronic liver disease: A marriage of many years. J. Molecules. 22 (191): 1-16.

Feher, J. and G. Lengyel. 2012. Silymarin in the prevention and treatment of liver diseases and primary liver cancer. Curr. Pharm. Biotechnol. 13: 210-217.

Friedwald, W. T., R. I. Leve and D. S. Fredrickson.1972. Estimation of the concentration of low-density lipoprotein separated by three different methods. Clin. Chem. 18: 499502.

Gazá, R., D. Walterová, and V. Kren. 2007. Silybin and silymarin new and emerging applications in medicine. Curr. Med. Chem. 14: 315-338.

Hartman, L. and R. C. A. Lago.1973. Rapid preparation of fatty acids methyle esters from lipids. Lab. Pract.22: 475.

Heidarian, E. and M. Rafieian-Kopaei.2012. Effect of silymarin on liver phoshpatidate phosphohydrolase in hyperlipidemic rats. Biosci. Res. 9 (2): 59-67.

Hsu, L. S., H. H. Ho, M. C. Lin, C. C. Chyau, J. S. Peng and C. J. Wang. 2012. Mulberry water extracts (MWEs) ameliorated carbon tetrachloride-induced liver damages in rat. Food \& Chem. Toxicol. 50(9): 3086-3093.

Hussein, E. A. and S. H. N. Salah. 2016. Comparative study between drug and fresh parsley at different levels on hepatotoxic rats. $4^{\text {th }}$ International $-18^{\text {th }}$ Arab conference of Home Economics" Home Economics and development. 5-6: 103-118.

Imamoto, R., J. I. Okano, S. Sawada, Y. Fujise, R. Abe and Y. Murawaki.2014. Null anticarcinogenic effect of silymarin on diethylnitrosamine-induced hepatocarcinogenesis in rats. Experimental and Therapeutic Medicine. 7: 31-38.

Ismael, S. M., A. M. Farahat, Y. M. Ebrahim and S. T. Gohari. 2014. Functional and nutritional properties of stirred yoghurt supplemented with silymarin and its impact on chronic hepatic damage. World J. Dairy \& Food Sci.9 (1): $36-50$

Jendrassik, L. 1938. Calorimetric determination of bilirubin. Biochem., 97: 72-81.
Kanter, M., I. Meral, S. Dede, H. Gunduz, M. Cemek, H. Ozbek and I. Uygan. 2003.Effects of Nigella sativa L. and Urtica dioica $L$. on lipid peroxidation, antioxidant enzyme systems and some liver enzymes in $\mathrm{CCl}_{4}$ treated rats. J. Vet. Med. A. Physiol. Pathol. Med. 50(5): 264-268.

Larsen, K. 1972. Creatinine assay by a reaction- kinetic principle. Clin. Chim. Acta. 41: 208- 209.

Lee, G. P., W. I. Jeong, J H. D.eong, T. H. Kim and K. S. Jeong. 2005. Diagnostic evaluation of carbon tetrachloride induced rat hepatic cirrhosis model. Anticancer Res. 25(2A): 1029-1038.

Lien, D. T. P., C. T. K. Hoang, N. Thi Hanh, D. X. Chu, P. T. B. Tram and H. T. Toan. 2016. Hepatoprotective effect of silymarin on chronic hepatotoxicity in mice induced by carbon tetrachloride. J. Pharm. Phytochem. 5(5): 262-266.

Lopes, M., S. Stone, S. Ellis, and J. Collwell. 1977. Cholesterol determined in high denisty lipoprotein separated by three different methods. Clin. Chem. 23 (5): 882-884.

Mahli, A., A. Koch, B. Czech, P. Peterburs, A. Lechner, J. Haunschild, M. Müller and C. Hellerbrand. 2015. Hepatoprotective effect of oral application of a silymarin extract in carbon tetrachloride-induced hepatotoxicity in rats. Clinical Phytoscience. 1(5): 2-8.

N.R.C. 1995. National research council. Nutrition Requirements of Laboratory Animals, $4^{\text {th }}$ revised edition, pp 29-30. National Academy press. Washington, D.C, U.S.A.

Ozturk, M., M. Akdogan, I. Keskin, A. N. Kisioglu, S. Oztas and K. Yildiz. 2012. Effect of Silybum marianum on acute hepatic damage caused by carbon tetrachloride in rats. Biomed. Res. 23 (2): 268-274.

Post-White, J., E. J. Ladas and K. M. Kelly. 2007. Advances in the use of milk thistle (Silybum marianum). Integr. Cancer Ther., 6: 104-109.

Rainone, F. 2005. Milk thistle. Am. Fam. Physician. 72: 12851288.

Retiman, S. and S. Frankel. 1957. A colorimetric method for the determination of serum glutamic oxaloacetic and glutamic pyruvic transaminases. Am. J. Clin. Path., 28: 56-58.

Skottová, N., R. Večeřa, K. Urbánek, P. Vána, D. Walterová and L. Cvak. 2003. Effects of polyphenolic fraction of silymarin on lipoprotein profile in rats fed cholesterolrich diets. Pharmacol. Res. 47: 17-26.

Sonnenwirth, A. and L. Jaret. 1980. Grade wholes clinical laboratory methods and diagnosis. $18^{\text {th }}$ ed. Mosby. London.U.K. pp.258-259.

Stein, E. A. 1987. Lipids, Lipoproteins, and Apolipoproteins. In: Tietz NW, ed. Fundamentals of Clin. Chem. $3^{\text {rd }}$ ed. Philadelphia: WB Saunders. pp. 448-481.

Suja, S. R., P. G. Latha, P.P ushpangadan and S. Rajasekharan. 2004. Evaluation of hepatoprotective effects of Helminthostachys zeylanica L hook against carbon tetrachloride- induced liver damage in Wistar rats. J. Ethnopharmacol. 92: 61-66. 
Suvarna, S. K., C. Lyton, and J. D. Bancroft. 2013. Bancroft,s Theory and Practico of Histological Techniggues.7 th Ed. Churechill Livingstone. Elsevier.England.

Theriault, A., Q. Wang, S. C. Van Iderstine, B. Chen, A. A. Franke, and K. Adeli. 2000. Modulation of hepatic lipoprotein synthesis and secretion by taxifolin, a plant flavonoid. J. Lipid Res. 41: 1969-1979.
Wahid, A., A. N. Hamed, H. M. Eltahir and M. M. Abouzied. 2016. Hepatoprotective activity of ethanolic extract of Salix subserrata against $\mathrm{CCl}_{4}$ induced chronic hepatotoxicity in rats. BMC Complementary \& Altern. Med. 16: 263-273.

Young, D. S. 2001. Effects of Disease on Clinical Lab. Tests, $4^{\text {th }}$ ed. AACC.

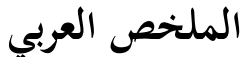

التاثير العلاجى لبذور شوك الجمل (Silybum marianum L)على الفئران المصابة بالتسمم الكبدى بواسطة رابع كلوريد الكريون

$$
\text { داليا أحمد زكى، عزة صبيح عبد الغنى، أيمن جمعة }
$$

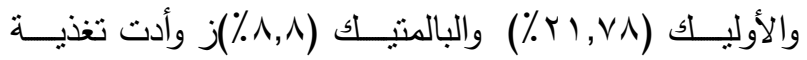
الفئران المصـابة بالتسمم الكبدى على نسبة ؟ ب\% من بذور

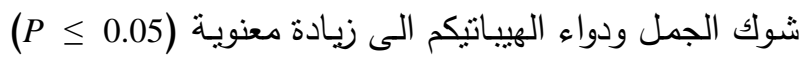
في وزن كبد الفئران مقارنة بالمجموعة الضابطة الموجبة. في حين لم تكن هناك فروق معنوية (P 20.05 > بين المجموعة

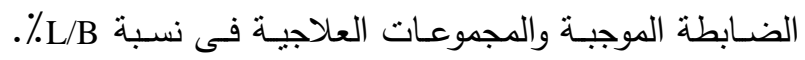
كما أدى إضـافة ب و r ٪ من تلك البذور للوجبة الأساسية إلى انخفاض معنوى (PS 1 (P) في مستوى نشاط انزيمات الكبـ ALT و AST مقارنــة بالمجموعـة الضـابطة الموجبـة، وأيضا حدث انخفاض معنوى في مسنويات اليوريا والكرياتنينين

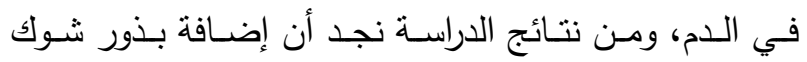

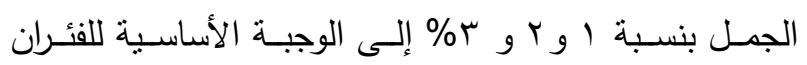
الكصابة بالتسمم الكبدى أدى الى تحسن معنوى في وظائف الكبد وكذلك نتائج الهستوباثولوجى. الكلمـات المفتاحيـة :بـذور شـوك الجمـل، التسـمم الكبـدى، الأحماض الدهنية، انزيمات الكبد ALT و. AST
يهذف هذا البحث إلى دراسة التاثير العلاجى لبذور شوك الجمل (Silybum marianum L) ومقارنته مع دواء الهيباتيكم على الفئران المصابة بالتسمم الكبدى الناتج عن الحقن برابع كلوريد الكربون. ولقد استخدم لذللك ستة وثلاثون من إناث الفئران البيضـاء تم تقسيمهم الى ست مجموعات متسـاوية، واستخدمت المجموعة الأولى كمجموعة ضـابطة سالبة أمسا

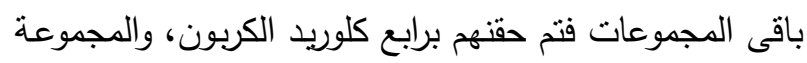
الثانية كانت تمثل المجموعة الضابطة الموجبة، أما المجموعة الثالثة والرابعة والخامسة فقد تم تغذيتهم على الوجبة الأساسية

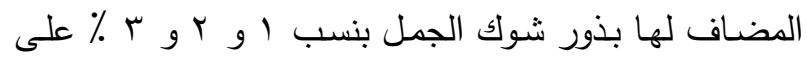
التوالي، والمجموعة السادسة تم تغذيتها على الوجبة الأساسية

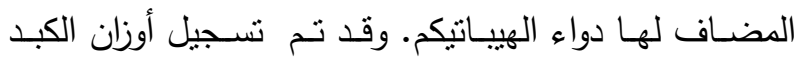
اللفئران وحساب نسبة وزن الكبد بالنسبة لوزن الجسم (L/B \%)

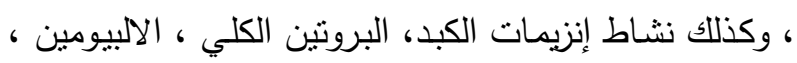

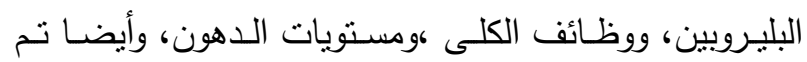

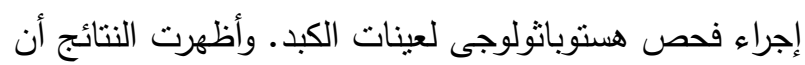
بذور شوك الجمل غنية بالبروتين والدهون والألياف، كذللك

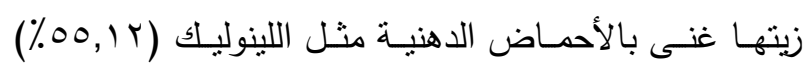

